\title{
The role of state archival sources in the study of the history of forestry in Uzbekistan (on the example of the Fergana valley)
}

\author{
Olimov Jaxongir \\ ${ }^{1}$ Kokand state pedagogical institute, \\ Kokand, Uzbekistan \\ Meliboyev Aziz ${ }^{2}$ \\ ${ }^{2}$ Kokand state pedagogical institute, \\ Kokand, Uzbekistan
}

\begin{abstract}
The study of the history of forestry in Uzbekistan is one of the goals of the environmental policy of the Republic of Uzbekistan, and the work done and achievements in this area have an important political and practical significance. This article examines the role and importance of state archival sources in the study of the history of forestry in Uzbekistan.
\end{abstract}

Keywords: rocks, forestry, forests, history, development, archive, regional archives, agriculture, irrigation, nature protection, natural resources.

\section{Introduction}

In studying the history of Uzbekistan, it is very important to study the history of the fields. Scientific research ( $\mathrm{PhD}$, doctoral dissertations) has been conducted and is being conducted on such topics as agriculture of Uzbekistan: silkworm breeding, cotton growing, irrigation, the history of the development of Mirzachul. In this sense, the study of the history of the forestry sector of agriculture is also relevant.

The study of the history of forestry in Uzbekistan is one of the goals of the environmental policy of the Republic of Uzbekistan, and the work done and achievements in this area have an important political and practical significance. After all, the historical and legal basis for the protection of forestry created and developed in our country and the practice of its implementation are essentially aimed at ensuring human environmental rights. In addition, one of the important aspects of nature protection and rational use of natural resources is the preservation and improvement of forestry conditions.

When studying the history of forestry of Andijan region in the regional state archive, the documents of 1947-1969 were obtained in the amount of 9639 with a volume of 70 volumes. Documents in the archives: - work plans; - annual accounting reports; - production financial plans; Tables of places. Boz Forestry 639-fund 28-storage unit 1950-1955 Resolutions of the Andijan regional executive committee. The stored documents are: - Documents on the organization of forestry; administrative orders; - plans, analysis of implementation; - annual reports; - table of places; - decisions of the trade union organization. From 1946 he worked under the leadership of the Variety Testing Inspectorate under the Ministry of Agriculture of the Uzbek SSR, from 1940 to 1953 the following documents were kept permanently: - the people; commissariat orders; - production financial plans; Variety testing plans.

\section{Main part}

In the state archives of Fergana region we can see many sources on the history of forestry. The main sources in the study of the history of this field are mainly in the fund №809. № In the 1st list of 809 funds there are 26 volumes of documents of the Fergana regional forestry for 1934-1948. The documents received are: - documents on the organization of forestry; - administrative orders; - Analysis of plans, work performed; - annual reports; - table of places; - Decisions of the trade union organization. In the second list, 23 funds for 1948-1962 are in permanent custody. In particular, in the 2nd case of the 2nd list, the orders on the decisions and measures taken by the district executive committee of Buvayda, Akhunboboev, Baghdad and Oltiarik districts of Fergana region on nature protection are kept.

The 6th set contains orders from the Ministry of Agriculture of Uzbekistan to direct the activities of the Fergana Regional Department of Agriculture. For example, in the Galaba collective farm alone, seventy thousand saplings are planned to be planted for protection, and the forestry is responsible for 
the supply of these saplings. We can see the information on the measures taken at the expense of the fund in the 14th set of this fund, which helped to prevent the negative consequences of the establishment of artificial fisheries in Buvayda district, such as deforestation and salinization of state farm lands. Information on the activities carried out in cooperation with the farm can be seen in the case 18,22 of the fund 809 .

We all know that during the Soviet era, the lack of land plots for housing caused serious problems. In this regard, the Fergana Forestry has signed agreements with the Regional Department of Electric Networks, Housing Construction, Regional Water Supply and Sewerage, aimed at building permanent and seasonal housing for its population and providing them with electricity and clean drinking water (№809 fond 47). - work) is reflected. As a result, by 1965, 860 families had permanent housing in the Kokand forestry area alone. In turn, the Fergana General Directorate of Forestry has been responsible for providing these families with jobs and creating conditions for their children's education. As a result of this work, new settlements have emerged, such as: "Peace", "Coast", "New Life".

№ 809 Fund List 4 contains a total of 52 funds for 1966-1994, which include annual reports, Accounting reports, 33 cases, reports on the main activities of the sector, and 33 cases - orders of the Department of Forestry of Fergana region; .

In addition to the above-mentioned fund in the study of the history of forestry in Fergana region, we can also obtain information through the card indexes of the State Archives of Fergana region. For example, №1022 fund, case 112, №324 fund 1-list, case 107, № 121 fund 2-list, case 220, № 26 fund 1list 35 , case 121 .

Fund 26, List 2, Case 222 contains the report of the Head of the Fergana Regional Forestry Department to the Regional Executive Committee, which states that in 1947 the main activities of the Forestry Department were the establishment of subsidiary farms in the field. The work done in the development of subsidiary farms, including beekeeping, can be seen in the example of 17 beekeeping farms established in Margilan alone. It is obvious that the forestry workers of the region have made a worthy contribution to the reconstruction of the national economy after World War II.

\section{Analyses}

Similar information can be found in the Namangan Regional State Archive. The main archival fund of the Main Department of Forestry of Namangan region is №493, with a total of 429 collections in 2 lists, which help to study the history of forestry activities in Namangan region from 1946 to 1992.

It is reflected in the measures for the protection and development of forestry. The success of the task of building the material and technical base of the state is closely linked with the rapid involvement of large natural resources in the economy, which is the basis for the development of the national economy. In 1965-1970, the forestry of the Namangan region in the Zarbob, Urat-Aral, Terakzor and Posha-Amin regions was closed; In the forestry activity of Namangan region, various flower saplings were grown and delivered to all regions of the Republic, giving aesthetic pleasure to our people.

The forestry of Namangan region has also contributed to the expansion of orchards and the supply of fruit to our people by supplying various fruit and ornamental seedlings to neighboring Kyrgyzstan, Tajikistan and Turkmenistan. About 300 tons of apples, pears, cherries and other fruits were harvested from the 90-hectare orchard in the region in 1972. The existing 25 hectares have been expanded to 150 hectares by the end of the five-year period. In addition, the farm contributed to the supply of 100,000 brooms, $2,000 \mathrm{~kg}$ of rabbit meat, $.700 \mathrm{~kg}$ of honey and other products necessary for human consumption [1].

\section{Conclusions}

As a continuation of such work, in 1982, as a result of a certain amount of educational work in the orchards to improve the condition of the orchards and wait for the yield, 1000 tons of fresh fruit were delivered to the state.

We can see in case 9493 fund 1 list 429 that significant work has been done to encourage forestry workers and provide them with housing. In the program of permanent housing for employees for 1989-2000, 65 families were provided with housing in 1965-1976, while in the program for 19892000 it is planned to build 150 houses.

\section{Reference}

[1] Mirziyoyev Sh.M. "It simply came to our notice then "Improving our well-being is at the heart of all our efforts." People's Word Newspaper, February 25, 2017, № 41 issue.

[2] Irmatov E.K. Project probnoy ekspluatatsii mestorozhdeniya Kruk: Report on NIR / OAO "UzLITIneftgaz"; - Tashkent, 1986. 
[3] Irmatov E.K. Technological scheme of development of mestorozhdeniya Kruk / OAO UzLITIneftgaz; - Tashkent, 1989.

[4] Irmatov E.K. Analysis of the development of Kruk / UzbekNIPIneftegaz; Otvetsvenniy ispolnitel - Tashkent, 1994.

[5] Irmatov E.K. Project development mestorojdeniya Kruk: Report on NIR / OAO UzLITIneftegaz; Otvetstvenniy ispolnitel - Tashkent, 2002

[6] Namangan regional state archive fund 493, list 1, case 222. 